\title{
Some Nitrogen Rich Energetic Material Synthesis by Nucleophilic Substitution Reaction from Polynitro Aromatic Compounds
}

\author{
Kübra Gürpınar, ${ }^{1}$ Yaprak Gürsoy Tuncer, ${ }^{1}$ Ş. Betül Sopacı, ${ }^{2}$ \\ M. Abdulkadir Akay, ${ }^{1}$ Hasan Nazır, ${ }^{1}$ Ingrid Svoboda, ${ }^{3}$ Orhan Atakol ${ }^{1}$ \\ and Emine Kübra İnal ${ }^{1, *}$ \\ ${ }^{1}$ Ankara University, Faculty of Science, Department of Chemistry, 06100, Ankara, Turkey \\ ${ }^{2}$ Kirşehir Ahi Evran University, Faculty of Art and Science, Department of Chemistry, 40100, Kirşehir, Turkey \\ ${ }^{3}$ TU-Darmstadt, Materialwissenschaft, Strukturforschung, Alarich-Weiss Strasse 2, 64287, Darmstadt, Germany \\ *Corresponding author: E-mail: inal@science.ankara.edu.tr
}

Received: 04-22-2021

\begin{abstract}
Three new nitrogen-rich energetic compounds, $N$-(5-chloro-2,4-dinitrophenyl)hydrazine (1), $N$-(5-chloro-2,4-dinitrophenyl)guanidine (2) and $N$-(5-chloro-2,4-dinitrophenyl)-4-aminopyrazole (3) prepared by the nucleophilic substitution reaction of 1,3-dichloro-4,6-dinitrobenzene with hydrazine, guanidinium carbonate and 4-aminopyrazole. The compounds were characterized by ${ }^{1} \mathrm{H}$ NMR, ${ }^{13} \mathrm{C}$ NMR, IR and mass spectroscopy. Only compound 2 could be prepared in a suitable crystal and molecular model was determined by X-ray analysis. Compounds were investigated by TG and DSC. Thermal degradation and thermokinetic behavior were investigated by Ozawa-Flynn-Wall and Kissinger-Akahira-Sunose techniques. Compounds were observed to be prone to exothermical thermal decomposition. HOMO and LUMO levels, theoretical formation enthalpy and electrostatic maps were calculated by Gaussian09. The detonation velocity and pressure were calculated by Kamlet-Jacobs equation. The compounds were assayed for antimicrobial properties.
\end{abstract}

Keywords: Energetic material; nitrogen-rich material; formation enthalpy; thermokinetic analysis; Kamlet-Jacobs equation; antimicrobial activity

\section{Introduction}

As known, in today's energetic research, the aim is to produce nitrogen-rich energetic materials. ${ }^{1-3}$ In explosion reactions, nitrogen atoms are assumed to turn into $\mathrm{N}_{2}$ gas. The $\mathrm{N}_{2}$ molecule is very stable, and therefore, the higher the number of nitrogen atoms in the energetic molecule, the higher the enthalpy of the explosion reaction. ${ }^{3}$ In this study, according to this suggestion, three new nitrogen-rich energetic materials were prepared using nucleophilic substitution reactions and examined by thermal analysis methods. Starting from this fact, 1,3-dichloro-4,6-dinitrobenzene is reacted with three nitrogen-rich nucleophiles, namely hydrazine, guanidine and 4-aminopyrazole in non-aqueous solvents and thus are prepared three new nitrogen-rich energetic materials, $N$-(5-chloro-2,4-dinitrophenyl)hy- drazine, $N$-(5-chloro-2,4-dinitrophenyl)guanidine and $\mathrm{N}$-(5-chloro-2,4-dinitrophenyl)-4-aminopyrazole (Figure 1).

In the aromatic ring, usually, nucleophilic substitution reactions do not occur, on the contrary, electrophilic substitution reactions occur. But nitro groups can change the behavior of the aromatic ring and nitro group is a strong electron-withdrawing group and it strongly affects the electron distribution of the molecule to which it is attached. ${ }^{4-6}$ Although many aromatic substances predominantly undergo electrophilic substitution reactions, when more than one nitro group is bonded to the aromatic ring the electron density of the aromatic ring decreases due to the high electron withdrawing effect of the nitro groups, and this ring can then undergo nucleophilic substitution reactions and the electron distribution of the ring is unbal- 

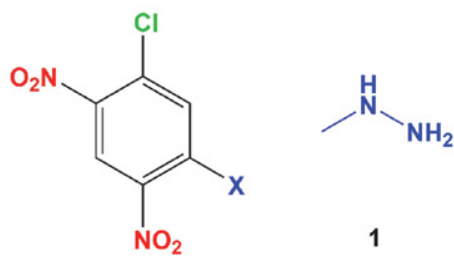

Figure 1. The structural formulas of the nitrogen-rich energetic materials.

anced. ${ }^{7-9} \mathrm{~A}$ large number of energetic substances prepared by this method were reported in the literature. ${ }^{10-14}$

Our choice of hydrazine and guanidine is since they are rich in nitrogen and the choice of 4-aminopyrazole is because of its heterocyclic structure. If hydrazine and guanidine are employed in nucleophilic substitution reactions, it is highly probable that two amino groups may be substituted which may result in symmetric molecules and the final product is a mixture. To obviate such a situation, guanidinium carbonate and hydrazine were added above their stoichiometric quantities. Since the second nucleophilic substitution is much more cumbersome after the first one, we only carried out one substitution. Before anything else, these energetic compounds were characterized by the use of $\mathrm{C}, \mathrm{H}, \mathrm{N}$ element analysis, IR spectroscopy and then their structures were elucidated by ${ }^{1} \mathrm{H}$ NMR and ${ }^{13} \mathrm{C}$ NMR spectroscopy after determining the molecular signals from direct inlet (DI) unit of mass spectroscopy. Among these energetic materials, only $\mathrm{N}$-(5-chloro-2,4-dinitrophenyl) guanidine was obtained as suitable crystals for the determination of its molecular structure and unit cell parameters by the use of X-ray diffraction methods. Then, the thermal decomposition of the compounds was examined by TG at different heating rates. The TG data obtained were used in the determination of activation energy $\left(E_{\mathrm{a}}\right)$ and pre-exponential factor $A$ of the thermal decomposition reactions utilizing the nonisothermal-isoconvertional Ozawa-Flynn-Wall (OFW) $)^{15-23}$ and Kissinger-Akahira-Sunose (KAS) ${ }^{19-26}$ and isothermal Coats-Redfern (CR $)^{27-29}$ methods.

Also, theoretical calculations were made using the basic set programs included in the Gaussian program in molecules. ${ }^{30}$ First, the theoretical formation enthalpies of the energetic materials were calculated by the use of the CBS-4M algorithm present in Gaussian09 software. Then the electron distribution and dipole moments of the energetic molecules were determined using DFT method and the differences between HOMO and LUMO of the energetic material were computed and evaluated. Finally, the detonation pressure and detonation velocity of the energetic materials prepared were calculated theoretically according to the literature. ${ }^{3}$

The energetic materials were also subjected to antimicrobial activity tests due to the lack of these types of tests in the literature using seven different bacteria, namely Escherichia coli, Pseudomonas aeruginosa, Salmonella en- teritidis, Enterococcus faecalis, Bacillus subtilis, Staphilococcus aureus, and Bacillus licheniformis. Anti-microbial activity results were evaluated according to the groups attached to the energetic compounds investigated. There are two important reasons for antimicrobial activity studies. The first one is to have a better insight into the effect of the groups attached to them. The energetic compounds are strained molecules due to nitro groups and these strained molecules can have highly anti-bacterial activity. Secondly, the energetic materials that contain nitrogen are of good nutritional value for the microscopic organisms and promote their growth. Therefore the microscopic investigation of these compounds is of great importance as regards the protection of the environment and human health.

\section{Experimental}

In the syntheses, 1,3-dichloro-4,6-dinitrobenzene, guanidinium carbonate, hydrazine hydrate and 4-aminopyrazole were used without previous purification. IR spectra were taken with a Shimadzu IRAffinity-1 FTIR spectrometer equipped with a three-reflection ATR unit, all IR spectra were recorded at a resolution of $4 \mathrm{~cm}^{-1}$. Thermal analyses were conducted with a Shimadzu DTG $60 \mathrm{H}$ and Shimadzu DSC 60 under $\mathrm{N}_{2}$ atmosphere with a heating rate of $10{ }^{\circ} \mathrm{C}$ $\mathrm{min}^{-1}$ in Pt pans. The temperature and heat calibrations of TG were carried out using In and Zn samples and DSC was calibrated using In. The NMR spectra of the ligands were recorded on a Varian Mercury $400 \mathrm{MHz}$ NMR spectrometer in DMSO- $d_{6}$. C, H, N elemental analyses were carried out using Eurovector 3018 CHNS analyzer. Electron impact mass spectra (EI-MS) were recorded on a Shimadzu QP2010 Plus GCMS apparatus equipped with a direct inlet unit.

\section{1. X-Ray Analysis}

A single crystal of compound 2 was analyzed with an Oxford Diffraction Xcalibur (TM) Single Crystal X-ray Diffractometer with a sapphire CCD detector using $\mathrm{MoK}_{\alpha}$ radiation $(\lambda=0.71073 \AA)$ operating in the $\omega / 2 \theta$ scan mode. The unit-cell dimensions were determined and refined by using the angular settings of 25 automatically centered reflections in $2.98 \leq \theta \leq 27.788$ range. The empirical absorption corrections were applied by the semi-empirical method via the CrysAlis CCD software. ${ }^{31}$ Models were obtained from the 
results of the cell refinement and the data reductions were carried out using the solution software SHELXL 2014-6. ${ }^{32}$ The structures of the energetic materials were resolved by direct methods implemented in the WinGX package. ${ }^{33}$

\section{2. Kinetic Analysis}

Kinetic analyses for the decomposition reactions of compounds 1, 2 and 3 were carried out by applying KAS, FOW and Coats-Redfern methods to thermograms at heating rates of $1.0,5.0,10.0,15.0,20.0$ and $25.0^{\circ} \mathrm{C} \mathrm{min}{ }^{-1}$ for 2 and 3; 0.5, 0.6, 0.75 and $1.0^{\circ} \mathrm{C} \mathrm{min}-1$ for 1 . Since 1.0 ${ }^{\circ} \mathrm{C} \mathrm{min}^{-1}$ heating rate leads to $\ln \beta=0$, the other heating rates were employed for FOW and KAS calculations; nonetheless, $1.0^{\circ} \mathrm{C} \mathrm{min}^{-1}$ was used in $\mathrm{CR}$ calculations. FOW calculation was not applicable to $\mathbf{1}$ because there was not sufficient data for the three heating rates used. The fact that the compound decomposes very rapidly at higher heating rates does not make any calculations possible.

The activation energies and pre-exponential factors were calculated with the help of graphical methods using the temperatures corresponding to $g(\alpha)$ values of $0.2,0.4$, $0.5,0.6$ and 0.8 at different heating rates according to both KAS and FOW methods. On the other hand, CR calculations were separately carried out at a chosen heating rate for different $g(\alpha)$ values.

The calculations were carried out by the use of KAS (1), FOW (2) and CR $(3,4)$ equations given below:

$$
\begin{aligned}
& \ln \frac{\beta}{T^{2}}=\ln \frac{A E_{a}}{R g(\alpha)}-\frac{E_{a}}{R T} \\
& \ln \beta=\ln \frac{0.0048 A E_{a}}{R g(\alpha)}-1.0516 \frac{E_{a}}{R T} \\
& \ln \frac{g(\alpha)}{T^{2}}=\ln \left[\frac{A R}{\beta E_{a}}\left(1-\frac{2 R T}{E_{a}}\right)\right]-\frac{E_{a}}{R T}
\end{aligned}
$$

Because of the term $\frac{2 R T}{E_{\alpha}}$ is $\leq 0.1$ in most cases the equation 3 is rearranged as.

$$
\ln \frac{g(\alpha)}{T^{2}}=\ln \left[\frac{A R}{\beta E_{a}}\right]-\frac{E_{a}}{R T}
$$

In the equations $\beta$ is the heating rate in ${ }^{\circ} \mathrm{C} \min ^{-1}, R$ is the universal gas constant, $E_{a}$ is the activation energy for thermal decomposition, $A$ is the Arrhenius pre-exponential factor, $T$ is the temperature in $\mathrm{K}$ and $g(\alpha)$ is the fraction of completion of the decomposition reaction. Note that these methods assume that the reaction order is 1 . There-

fore one can sketch the plots of $\ln \beta, \ln \frac{\beta}{T^{2}}$, and $\ln \frac{g(\alpha)}{T^{2}}$ against $\frac{1}{T} . E_{a}$ and $A$ values can simply be calculated using the slope and the intercept of these plots. Besides, employing $E_{a}$ and $A$ values, other thermodynamic parameters such as entropy $(S)$, enthalpy $(H)$ and Gibbs free energy $(G)$ changes for the thermal decompositions were calculated. The entropy change in a thermal reaction can be approximated by using the pre-exponential factor ${ }^{28}$ (Equations 5 and 6):

$$
\Delta S=2.303\left(\log \frac{A h}{k T}\right) R
$$

The change in enthalpy is calculated from the activation energy according to the first law of thermodynamics (Equation 6):

$$
\Delta H=E_{a}-R \Delta T
$$

Using these values the Gibbs free energy can be calculated from equation 7 :

$$
\Delta G=\Delta H-T \Delta S
$$

\subsection{Theoretical Calculation}

The enthalpies $(H)$ and free energies $(G)$ were calculated using the CBS-4M method embedded in the Gaussian G09 W (revision D.01) software package. ${ }^{30}$ The CBS-4M begins with a HF/3-21G(d) to structure optimization and zero-point energy calculations. Then using MP2/6-31+G

\begin{tabular}{|c|c|c|c|c|}
\hline Compound & p.g. ${ }^{\mathrm{a}}$ & NImag & $-H_{298} /$ a.u.c & $\Delta_{f} H^{\circ} / \mathrm{kJ} \mathrm{mol}^{-1}$ \\
\hline 1,3-dichloro-4,6-dinitrobenzene & $C 1$ & 0 & 1558.715040 & -3.30 \\
\hline 1 & $C 1$ & 0 & 1210.104523 & 119.57 \\
\hline 2 & $\mathrm{C} 1$ & 0 & 1303.467180 & 74.90 \\
\hline 3 & $C 1$ & 0 & 1379.535864 & 205.04 \\
\hline $\mathrm{C}$ & & & 37.786156 & $716.682^{\mathrm{d}}$ \\
\hline $\mathrm{H}$ & & & 0.500991 & $217.100^{\mathrm{d}}$ \\
\hline $\mathrm{N}$ & & & 54.522462 & $472.679^{d}$ \\
\hline $\mathrm{O}$ & & & 74.991202 & $249.178^{\mathrm{d}}$ \\
\hline
\end{tabular}
and MP4(SDQ)/6-31+G(d,p) basis sets it is possible to calculate the corrected energy and to estimate the correlation contributions of a higher-order respectively. The stabilization of the optimized structures was controlled by the number of imaginary $(\mathrm{NImag}=0)$ at the same theory level.

Table 1. CBS-4M results.

${ }^{\text {a }}$ Point group, ${ }^{b}$ Number of imaginary frequencies, ${ }^{\mathrm{c}} \mathrm{CBS}-4 \mathrm{M}$ calculated enthalpy, ${ }^{\mathrm{d}}$ Ref. 35 
The formation enthalpies were calculated according to the atomization energy method, with respect to the equation given below ${ }^{34-36}$ (Table 1).

$$
\Delta_{f} H^{0}(g, M)=H(M)-\sum_{\text {atoms }} H^{0}+\sum_{\text {atoms }} \Delta_{f} H^{0}
$$

In this equation, $\Delta_{f} H^{\circ}(g, M)$ stands for the gas-phase enthalpy of formation of the molecule $M$, under investigation, $H(M)$ represents the CBS-4M calculated enthalpy of the molecule $M\left(\mathrm{H}_{298}\right.$ in Table 1$), \Sigma_{\text {atoms }} H^{\circ}$ denotes the CBS-4 $\mathrm{M}$ calculated enthalpies for the individual atoms (1 a.u. $\left.=2625.50 \mathrm{~kJ} \mathrm{~mol}^{-1}\right)$, and $\Sigma_{\text {atoms }} \Delta_{f} H^{\circ}$ values were quoted from NIST database. ${ }^{37}$

Also, the detonation heat $(Q)$, detonation velocity $(D)$ and detonation pressure $\left(P_{C-I}\right)$ of the compounds were calculated using the Kamlet-Jacobs equation, using the theoretical density $(\rho)$ and oxygen balance $(\Omega)$ values according to the equation given below ${ }^{3}$ :

$$
\begin{aligned}
& P_{C-J}=15.88 \rho^{2} N M^{1 / 2} Q^{1 / 2}, \text { as kbar } \\
& D=1.01\left(N M^{1 / 2} Q^{1 / 2}\right)^{1 / 2}(1+1.30 \rho), \\
& \quad \text { as } \mathrm{mm} \mathrm{ss}^{-1} \text { or m s}^{-1}
\end{aligned}
$$

Here, $Q$ is the heat of explosion in $\mathrm{kcal} \mathrm{g}^{-1}, N$ is the number of moles gas per gram explosive and $M$ is the mass of gas in gram per mole of gas. The explosion reaction is written according to the oxygen balance equation. The detonation heat $(Q)$ is calculated according to Hess's law by using the moles of product in the explosion reaction, standard enthalpy of formation and theoretical enthalpy of formation of energetic compounds.

\section{4. Determination of Biological Activity}

Antibacterial activity was tested against Gram negative (E. coli, P. aeruginosa, S. enteritidis) and Gram positive (E. faecalis, B. subtilis, $S$. aureus, B. licheniformis) bacterial species. $^{24,38-40}$ Bacterial species were grown in Hinton Müeller Agar (HMA) and suspensions $\left(10^{6} \mathrm{cfu} / \mathrm{mL}\right)$ were prepared from $24 \mathrm{~h}$ cultures. $\mathrm{N}$-(5-chloro-2,4-dinitrophenyl)hydrazine (1), $\mathrm{N}$-(5-chloro-2,4-dinitrophenyl)guanidine (2) and $\mathrm{N}$-(5-chloro-2,4-dinitrophenyl)-4-aminopyrazole (3) suspensions were prepared in DMSO. Agar dilution tests were performed for Minimum Inhibitory Concentration (MIC) determination. $10 \mu \mathrm{L}$ bacterial suspensions were placed into plates and results were recorded after $24 \mathrm{~h}$ cultivation.

\section{5. Preparation of Energetic Materials}

Aromatic polynitrohalides can easily undergo nucleophilic substitution reactions. ${ }^{7,8}$ The energetic materials used in the study were prepared in hydrothermal conditions, accordingly chlorine atoms in 1,3-dichloro-4,6-dinitrobenzene can be replaced by strong nucleophiles. Since the nitrogen nucleophiles used are strong nucleophiles, the chlorine atom in 1,3-dichloro-4,6-dinitrobenzene and the amino groups of the nucleophile molecules were displaced in amphiprotic solvents under hydrothermal conditions in 2 or 3 hours of reaction time and energetic substances were obtained.

\section{Results and Discussion}

\section{1. Synthesis}

Three energetic compounds were prepared from amino compounds, hydrazine, guanidinium carbonate and 4-aminopyrazole with 1,3-dichloro-4,6-dinitrobenzene as a result of nucleophilic substitution reactions in $\mathrm{MeOH}$ or EtOH under reflux for 3 h. 4-Aminopyrazole was used in an equivalent amount of 1,3-dichloro-4,6-dinitrobenzene in the medium, while more than the equivalent amount of guanidinium carbonate and hydrazine was added to the medium. A second possibility expected here was the replacement of two chlorine atoms in 1,3-dichloro-4,6-dinitrobenzene and there was a possibility of a mixed product, but it was observed that a single chlorine was eventually replaced.

$\mathrm{N}$-(5-Chloro-2,4-dinitrophenyl)hydrazine (1). Yield 77$80 \%$. Anal. Calcd for $\mathrm{C}_{6} \mathrm{H}_{5} \mathrm{~N}_{4} \mathrm{O}_{4} \mathrm{Cl}$ : C, 30.98; H, 2.17; N, 24.08. Found: C, 31.34; H, 2.29; N, 24.02. ${ }^{1} \mathrm{H}$ NMR (DMSO- $\left.d_{6}\right) \delta 9.30(\mathrm{~s}, 1 \mathrm{H}$, broad), $8.88(\mathrm{~s}, 1 \mathrm{H}), 7.19(\mathrm{~s}, 1 \mathrm{H}), 4.75$ $(\mathrm{d}, J=0.004 \mathrm{~Hz}, 2 \mathrm{H}) .{ }^{13} \mathrm{C}$ NMR (DMSO- $\left.d_{6}\right) \delta 149.44$, 128.39, 122.35. IR, $v, \mathrm{~cm}^{-1}: 3462.22,3361.93,3265.49$ $(\mathrm{NH}), 3101.54(\mathrm{CH}), 1636.64(\mathrm{C}=\mathrm{N}), 1595.13(\mathrm{C}=\mathrm{C})$, $1280.73(\mathrm{~N}=\mathrm{O}), 837.11,738.14(\mathrm{CH}) . \mathrm{MS} m / z: 232[\mathrm{M}]^{+}$, $214,149,113,85,76,57,43$.

$\mathrm{N}$-(5-Chloro-2,4-dinitrophenyl)guanidine (2). Yield 8590\%. Anal. Calcd for $\mathrm{C}_{7} \mathrm{H}_{6} \mathrm{~N}_{5} \mathrm{O}_{4} \mathrm{Cl}$ : C, 32.29; $\mathrm{H}, 2.33$; N, 26.96. Found: C, 31.81; H, 2.53; N, 25.03. ${ }^{1} \mathrm{H}$ NMR (DM$\left.\mathrm{SO}-d_{6}\right) \delta 8.56(\mathrm{~s}, 1 \mathrm{H}), 8.48,(\mathrm{~s}, 1 \mathrm{H}), 7.72(\mathrm{~s}, 1 \mathrm{H}), 7.07(\mathrm{~s}$, $1 \mathrm{H}), 6.81\left(\mathrm{~s}, 2 \mathrm{H}\right.$, broad). ${ }^{13} \mathrm{C}$ NMR (DMSO- $\left.d_{6}\right) \delta 158.95$, 153.34, 151.01, 138.22, 132.69, 124.87. IR, v, $\mathrm{cm}^{-1}: 3462.22$, $3421.72,3381.90(\mathrm{NH}), 3101.54(\mathrm{CH}), 1636.64(\mathrm{C}=\mathrm{N})$, $1595.13,1550.77(\mathrm{C}=\mathrm{C}), 1280.73(\mathrm{~N}=\mathrm{O}), 827.44,738.79$ (CH). MS m/z: $259[\mathrm{M}]^{+}, 229,187,132,97,57,43$.

$\mathrm{N}$-(5-Chloro-2,4-dinitrophenyl)-4-aminopyrazole (3). Yield 67-70\%. Anal. Calcd for $\mathrm{C}_{9} \mathrm{H}_{6} \mathrm{~N}_{5} \mathrm{O}_{4} \mathrm{Cl}$ : C, 37.33; H, 2.13; N, 24.68. Found: C, 36.59; H, 2.45; N, 24.23. ${ }^{1} \mathrm{H}$ NMR $\left(\mathrm{DMSO}-d_{6}\right) \delta 12.81(\mathrm{~s}, 1 \mathrm{H}), 10.20(\mathrm{~s}, 1 \mathrm{H}), 8.86(\mathrm{~s}, 1 \mathrm{H}), 8.43$ $(\mathrm{s}, 1 \mathrm{H}), 7.79(\mathrm{~s}, 1 \mathrm{H}), 6.33(\mathrm{~s}, 1 \mathrm{H}) .{ }^{13} \mathrm{C}$ NMR $\left(\mathrm{DMSO}-d_{6}\right) \delta$ $146.93,142.53,134.89,133.40,129.99,126.07,119.31$, 98.26. IR, $v, \mathrm{~cm}^{-1}: 3310.42,3298.26(\mathrm{NH}), 3147.83(\mathrm{CH})$, $1610.56(\mathrm{C}=\mathrm{N}), 1591.27,1552.70(\mathrm{C}=\mathrm{C}), 1317.38(\mathrm{~N}=\mathrm{O})$, 827.46, $738.74(\mathrm{CH}) . \mathrm{MS} m / z: 283[\mathrm{M}]^{+}, 237,191,156,129$.

Warning: The synthesized compounds are in the energetic material class, working temperatures should be in 
hydrothermal conditions. High temperature may result in explosion and sample amount should not be higher than $10 \mathrm{mg}$ in thermal analysis experiments.

Elemental analysis results are in close agreement with expected values. Specific $\mathrm{N}-\mathrm{H}$ stretching vibrations in the IR spectra were observed at the expected value between $3462-3265 \mathrm{~cm}^{-1}$. It is thought that the middle signal observed at $1610-1636 \mathrm{~cm}^{-1}$ in three energetic materials is due to the $\mathrm{C}=\mathrm{N}$ imine bond formed as a result of resonance. $\mathrm{N}=\mathrm{O}$ stretching vibration signals of nitro groups were observed at $1280-1317 \mathrm{~cm}^{-1}$. In the EI-MS spectra, the molecular peaks $[\mathrm{M}]^{+}$were observed at the expected values and also as the base peak of the spectrum. The $m / z$ values of the $[\mathrm{M}]^{+}$signals are in agreement with the nitrogen rule.

In the ${ }^{1} \mathrm{H}$ NMR spectrum of $N$-(5-chloro-2,4-dinitrophenyl)hydrazine, 4 signals with $\delta$ values of $9.30,8.88,7.19$ and 4.75 were observed, respectively. This result is expected, because there are 4 different hydrogens in the molecule. It is probable that the signal observed at $\delta 9.30$ is the signal of the $\mathrm{NH}$ group proton and the signal observed at $\delta 4.75$ belongs to the $\mathrm{NH}_{2}$ group protons. In the ${ }^{13} \mathrm{C}$ NMR spectrum of this substance, 4 different signals are observed, actually the number of different carbon nuclei is 6 . It is possible that the signals of aromatic carbons with nitro groups and $\mathrm{H}$ bonded carbons signals overlap, because two signals in the spectrum were observed to be more intense than the others.

In the ${ }^{1} \mathrm{H}$ NMR spectrum of $N$-(2,4-dinitro-5-chlorophenyl)guanidine, 5 signals are observed with $\delta$ values of $8.56,8.48,7.72,7.07$ and 6.81 . There are 5 different types of hydrogen in the molecule, similarly, there are 7 different carbon nuclei in this molecule and as a result, 7 different signals were found in the ${ }^{13} \mathrm{C}$ NMR spectrum. Similarly, there are 6 different hydrogen atom nuclei in the $N$-(5-chloro-2,4-dinitrophenyl)-4-aminopyrazole molecule and 6 different signals are observed in the ${ }^{1} \mathrm{H}$ NMR spectrum. The signal of $\delta 12.81$ is most likely the signal of the hydrogen in the $\mathrm{NH}$ group of the pyrazole ring. There are 9 different carbon atoms in the $N$-(5-chloro-2,4-dini- trophenyl)-4-aminopyrazole molecule, but 8 signals are observed in the spectrum. It is possible that the two carbon signals in the pyrazole ring overlap.

\section{2. Thermal Analysis}

The TG plots of three new energetic materials at a heating rate of $15{ }^{\circ} \mathrm{C} \mathrm{min}-1$ are shown in Figure $2 \mathrm{a}$. The plots reveal the fact that $\mathrm{N}$-(5-chloro-2,4-dinitrophenyl) hydrazine (1) acts as a typical explosive. The compound shows a rapid mass loss at $235^{\circ} \mathrm{C}$ which culminates at 268 ${ }^{\circ} \mathrm{C}$ in a complete degradation with a mass loss of $97 \%$. On the other hand, the compounds $\mathrm{N}$-(5-chloro-2,4-dinitrophenyl)guanidine (2) and N-(5-chloro-2,4-dinitrophenyl)-4-aminopyrazole (3) display two decomposition processes in their respective TG plots. Figure $2 \mathrm{~b}$ shows the differential thermal analysis (DTA) curves of the energetic compounds investigated in this study. It is obvious that the decomposition is exothermic. The first mass losses of the thermal reactions of the compounds at a heating rate of

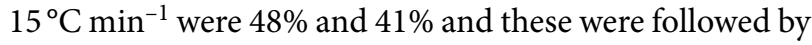
the second mass losses of $21 \%$ and $18 \%$.

Compound $\mathbf{1}$ gives a strong exothermic signal around $260{ }^{\circ} \mathrm{C}$ without a melting process. On the other hand, 2 starts to melt down at $215^{\circ} \mathrm{C}$ and gives three weak exothermic signals at 241,330 and $379{ }^{\circ} \mathrm{C}$ after $226^{\circ} \mathrm{C}$. Finally, 3 melts down at $189-190{ }^{\circ} \mathrm{C}$ and gives two weak exothermic signals at $351^{\circ} \mathrm{C}$ and $407^{\circ} \mathrm{C}$.

As seen from Figure $2 \mathrm{a}, 1$ gives a single step decomposition above a heating rate of $10^{\circ} \mathrm{C} \mathrm{min}-1$, this is exactly the behavior expected from a typical explosive compound. ${ }^{41}$ However, it gives a two-step decomposition below this critical value. Figures $3 \mathrm{a}$ and $3 \mathrm{~b}$ show TG and DTA curves at scan rates of $0.6,0.75,1.0$ and $5.0{ }^{\circ} \mathrm{C} \mathrm{min}^{-1}$. Figure $3 \mathrm{a}$ shows that the mass loss takes place slowly at the first step and in an explosive manner in the second step. As the heating rate is increased, the second step appears more distinctively. The DTA curves given in Figures $2 \mathrm{~b}$ and $3 \mathrm{~b}$ are not in the expected format. The curves display first an
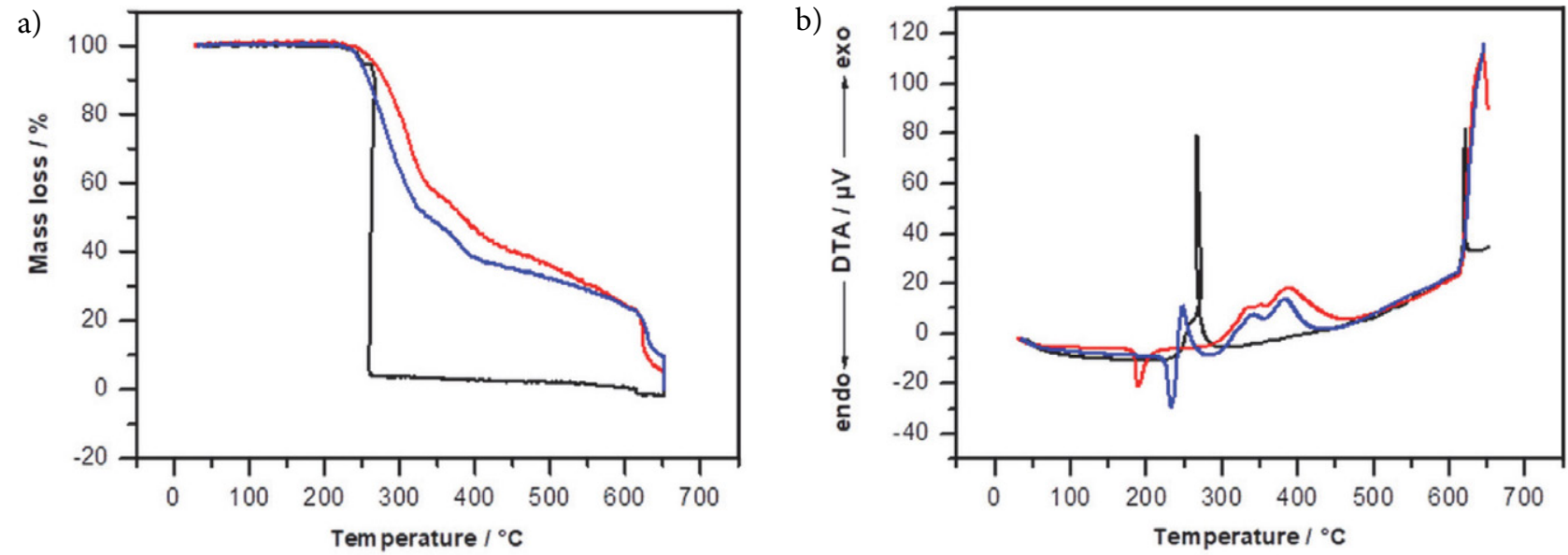

Figure 2. a. Thermogravimetric curves at $15{ }^{\circ} \mathrm{C} \min ^{-1}$ heating rate, b. DTA curves [black: $N$-(5-chloro-2,4-dinitrophenyl)hydrazine (1), blue: $\mathrm{N}$-(5-chloro-2,4-dinitrophenyl)guanidine (2), red: $\mathrm{N}$-(5-chloro-2,4-dinitrophenyl)-4-aminopyrazole (3)]. 
a)

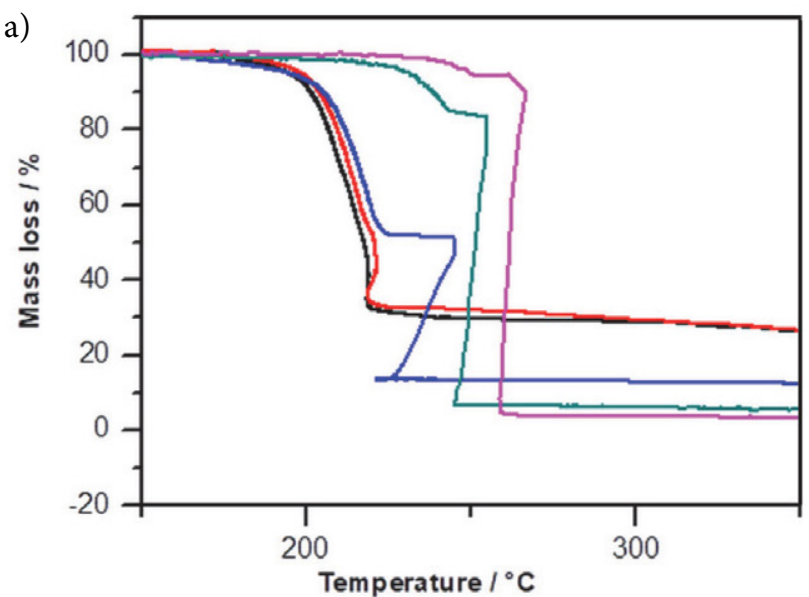

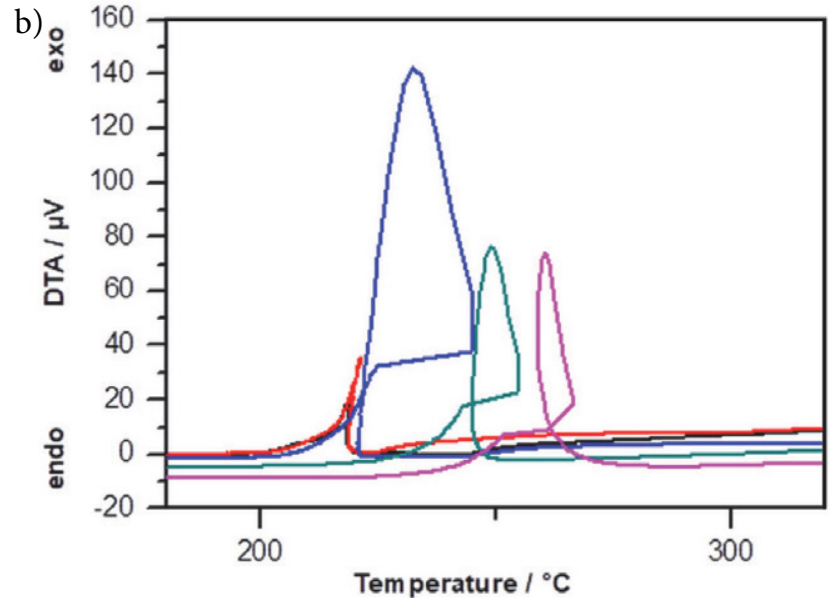

Figure 3. a. Thermogravimetric curves, b. DTA curves of $N$-(5-chloro-2,4-dinitrophenyl)hydrazine (1) recorded at different low heating rates [black: $0.6^{\circ} \mathrm{C} \min ^{-1}$, red: $0.75^{\circ} \mathrm{C} \min ^{-1}$, blue: $1^{\circ} \mathrm{C} \mathrm{min}^{-1}$, darkcyan: $5^{\circ} \mathrm{C} \mathrm{min}-1$, purple: $15^{\circ} \mathrm{C} \min ^{-1}$ ].
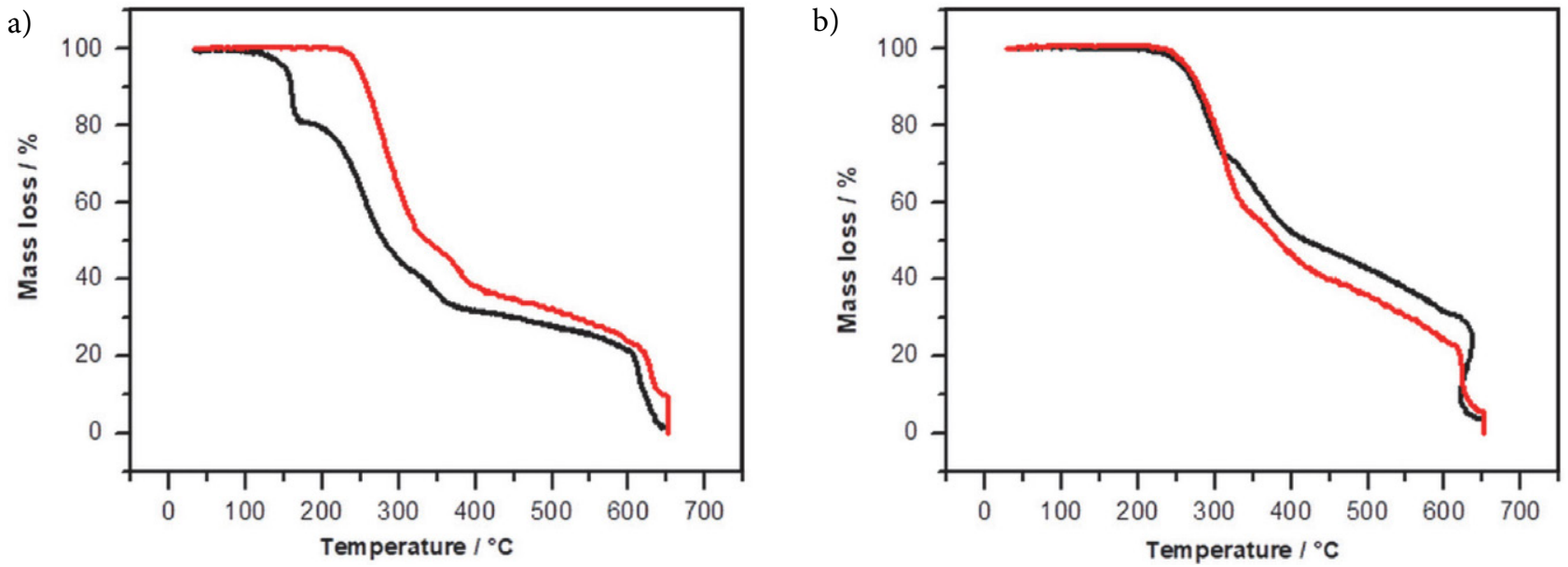

Figure 4. TG curves at different heating rate a. $N$-(5-chloro-2,4-dinitrophenyl)guanidine (2), b. $N$-(5-chloro-2,4-dinitrophenyl)-4-aminopyrazole (3) [black: $5^{\circ} \mathrm{C} \mathrm{min}^{-1}$, red: $15^{\circ} \mathrm{C} \mathrm{min}^{-1}$ ].

increase then a decrease in temperature. The reason for that is thermal decomposition taking place with an explosion. In a rapid explosion reaction, the gas products leave the pan rapidly taking away the heat they absorbed with them. This decreases the temperature of the pan resulting in the abnormal curves given in Figures $2 \mathrm{~b}$ and $3 \mathrm{~b}$.

A similar case exists for the energetic materials of 2 and $\mathbf{3}$ as the heating rate has decreased the shape and mass loss of TG curves change. Figure 4a shows the TG curves of energetic material of $\mathbf{2}$ recorded at two different heating rates. Figure $4 \mathrm{~b}$ illustrates analogous curves for 3 . The shapes of the curves change at lower heating rates. The thermoanalytical data belonging to TG-DTA curves of the energetic compounds prepared in this study are listed in Table 2.

When TG curves are examined in Figure 2a, at a heating rate of $15^{\circ} \mathrm{C} \mathrm{min}{ }^{-1}$, the compound 1 undergoes a complete single-step decomposition with almost a complete mass loss between $250-260{ }^{\circ} \mathrm{C}$ just like an explosive material. The other two materials, on the other hand, give two distinctive reactions at the same heating state. However, these TG curves change at lower heating rates. The compound $\mathbf{1}$ is observed to give a distinct two-step reaction at a heating rate of $5^{\circ} \mathrm{C} \mathrm{min}^{-1}$ or lower (Figures $3 \mathrm{a}$ and $3 \mathrm{~b})$. TG curves of compounds $\mathbf{2}$ and $\mathbf{3}$ vary with decreasing heating rates.

The fact that compounds 2 and 3 show distinct changes at $5{ }^{\circ} \mathrm{C} \mathrm{min}^{-1}$ is apparent in Figure 4. The decompositions of compounds $\mathbf{2}$ and $\mathbf{3}$ in two steps are more clearly observed at low heating rates. The mass losses of compounds 2 and 3 are $65 \%$ and 56\%, respectively as a result of thermal decomposition.

A fact that is known about energetic materials since 1958 is that if there is a nitrogen-containing group neighboring a nitro group, the thermal decomposition takes place though a furoxan ring., ${ }^{8,42-45}$ This situation is particularly apparent in picrylazide molecule where the $1^{\text {st }}$ nitrogen of the azide group forms a furoxan ring with the oxygen of the neighboring nitro group releasing two nitrogens of the azide group as an $\mathrm{N}_{2}$ molecule. ${ }^{11,42}$ If the heating 
process continues, the resulting furoxan will also decompose. A similar case exists for the compounds investigated here. Figure 5 shows the furoxan conversion reactions of the compounds prepared. As a result of the decomposition process, it is thought that 5-chloro-6-nitrofuroxane is formed by the release of a small group in gaseous form. Table 2 lists the thermoanalytical results drawn from the TG data. The mass losses for the first stage of decomposition at a thermal heating rate of $5{ }^{\circ} \mathrm{C} \mathrm{min}^{-1}$ for compounds
2 and 3 are $16.89 \pm 0.46$ and $25.76 \pm 1.08$. In Figure 5 the theoretical mass loss values of energetic compounds 2 and 3 for the second step were $16.95 \%$ and $24 \%$. These results prove that the first stage thermal decomposition reaction of compounds $\mathbf{2}$ and $\mathbf{3}$ takes place as written below. However since the thermal decomposition rate of compound $\mathbf{1}$ is much higher than those of compounds $\mathbf{2}$ and $\mathbf{3}$, it was not possible to accurately define its mass losses at the first and second stage decomposition reactions even at very low<smiles>NNc1cc(Cl)c([N+](=O)[O-])cc1[N+](=O)[O-]</smiles>

(1)<smiles>N=C(N)Nc1cc(Cl)c([N+](=O)[O-])cc1[N+](=O)[O-]</smiles>

(2)<smiles>O=[N+]([O-])c1cc([N+](=O)[O-])c(Nc2cn[nH]c2)cc1Cl</smiles>

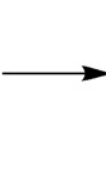<smiles></smiles><smiles>C=CC</smiles><smiles>O=[N+]([O-])c1cc2c(cc1Cl)no[n+]2[O-]</smiles>

$+\mathrm{HCN}(\mathrm{g})+\mathrm{NH}_{3}(\mathrm{~g})$

(3)

Figure 5. Probable first decomposition reaction of the energetic materials prepared.

Table 2. Thermoanalytical data of energetic materials prepared.

\begin{tabular}{|c|c|c|c|c|c|c|}
\hline \multirow[b]{2}{*}{$\begin{array}{l}\text { Energetic } \\
\text { Compound }\end{array}$} & \multirow{2}{*}{$\begin{array}{c}\text { M.P. } \\
{ }^{\circ} \mathrm{C}\end{array}$} & \multirow[b]{2}{*}{ 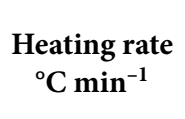 } & \multicolumn{2}{|c|}{ First Thermal Reaction } & \multicolumn{2}{|c|}{ Second Thermal Reaction } \\
\hline & & & $\begin{array}{l}\text { Temperature } \\
\text { range } /{ }^{\circ} \mathrm{C}\end{array}$ & $\begin{array}{l}\text { Mass } \\
\text { loss / \% }\end{array}$ & $\begin{array}{l}\text { Temperature } \\
\text { range } /{ }^{\circ} \mathrm{C}\end{array}$ & $\begin{array}{l}\text { Mass } \\
\text { loss / \% }\end{array}$ \\
\hline \multirow{2}{*}{$\begin{array}{l}N \text {-(5-chloro-2,4-dinitrophenyl) } \\
\text { hydrazine } \\
\text { (1) }\end{array}$} & \multirow{2}{*}{$\mathrm{NO}$} & 5 & $\begin{array}{l}211-240 \\
\text { DTA peak: } 216\end{array}$ & $94.73 \pm 0.87$ & - & - \\
\hline & & 15 & $\begin{array}{l}236-268 \\
\text { DTA peak: } 261\end{array}$ & $96.76 \pm 0.48$ & - & - \\
\hline \multirow{2}{*}{$\begin{array}{l}N \text {-(5-chloro-2,4-dinitrophenyl) } \\
\text { guanidine } \\
\text { (2) }\end{array}$} & \multirow{2}{*}{$\mathrm{NO}$} & 5 & $\begin{array}{l}\text { 144-173 } \\
\text { DTA peak: } 162\end{array}$ & $16.89 \pm 0.46$ & $\begin{array}{l}\text { 201-384 } \\
\text { DTA peak: } 353\end{array}$ & $49.20 \pm 3.45$ \\
\hline & & 15 & $\begin{array}{l}228-347 \\
\text { DTA peak: } 241\end{array}$ & $48.2 \pm 2.64$ & $\begin{array}{l}347-426 \\
\text { DTA peak: } 379\end{array}$ & $17.23 \pm 2.92$ \\
\hline \multirow{2}{*}{$\begin{array}{l}\mathrm{N} \text {-(5-chloro-2,4-dinitrophenyl)- } \\
\text { 4-aminopyrazole } \\
\text { (3) }\end{array}$} & \multirow{2}{*}{188} & 5 & $\begin{array}{l}221-307 \\
\text { DTA peak: } 293\end{array}$ & $25.76 \pm 1.08$ & $\begin{array}{l}311-407 \\
\text { DTA peak: } 351\end{array}$ & $26.15 \pm 1.23$ \\
\hline & & 15 & $\begin{array}{l}235-338 \\
\text { DTA peak: } 322\end{array}$ & $41.13 \pm 3.19$ & $\begin{array}{l}338-420 \\
\text { DTA peak:379 }\end{array}$ & $15.23 \pm 2.07$ \\
\hline
\end{tabular}

NO: Not observed 
heating rates. Although the decomposition reaction is observed to take place in two staged manners at low heating rates in Figure 3a the mass loss is erratic. Especially since the second thermal decomposition reaction is very fast, there were observed anomalies both in TG and DTA curves. Nevertheless, if one looks at TG curve of compound 1 at $5{ }^{\circ} \mathrm{C} \mathrm{min}^{-1}$ one sees that it is a two-stage process. It is seen that there is a small mass loss at the beginning in both the TG curves taken at heating rates of $5{ }^{\circ} \mathrm{C}$ $\min ^{-1}$ and $15^{\circ} \mathrm{C} \min ^{-1}$. However, the mass loss observed at the start constantly increases with the heating rate which makes it impossible to do any calculations for compound $\mathbf{1}$.

\section{3. X-Ray Studies}

Only compound $\mathbf{2}$ amongst the energetic materials prepared in this study was obtained in suitable crystal size therefore only the structure of this compound was deter- a)

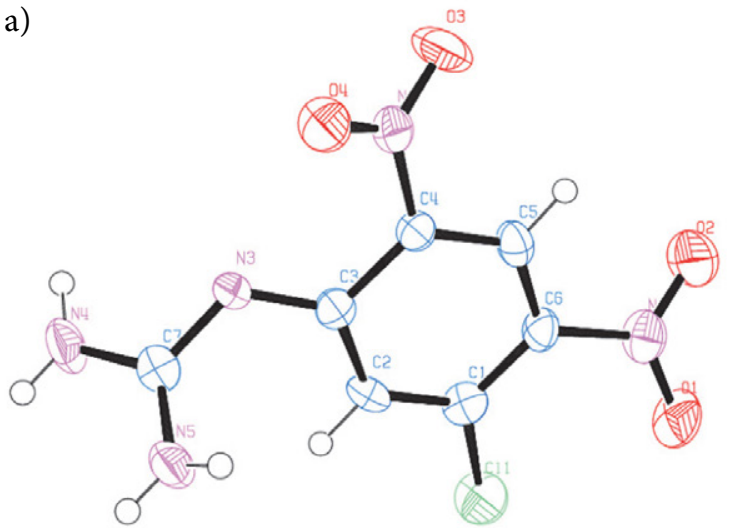

b)

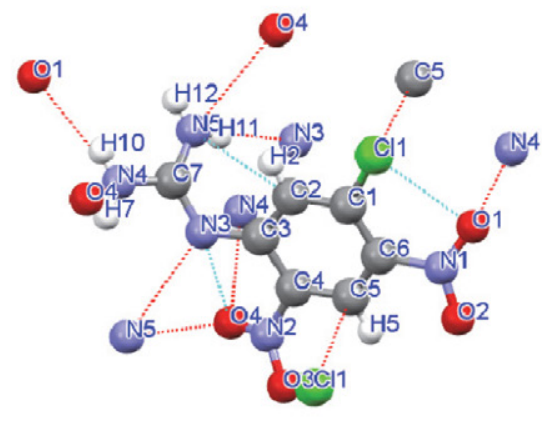

Figure 6. a. The Ortep drawing of $N$-(5-chloro-2,4-dinitrophenyl)guanidine (2), b. inter- and intramolecular hydrogen bonds and other interactions of $N$-(5-chloro-2,4-dinitrophenyl)guanidine (2), obtained using Mercury software.

Table 3. N-(5-chloro-2,4-dinitrophenyl)guanidine (2) crystal data and data collection conditions.

\begin{tabular}{|c|c|c|c|}
\hline Molecular Formula & $\mathrm{C}_{7} \mathrm{H}_{6} \mathrm{ClN}_{5} \mathrm{O}_{4}$ & Molar Mass/g mol ${ }^{-1}$ & 259.62 \\
\hline $\mathbf{T} / \mathbf{K}$ & 293(2) & $F(000)$ & 528 \\
\hline Crystal Colour & yellow & Crystal System & orthorombic \\
\hline Space Group & Pna2 & Index Ranges & $\begin{array}{l}-5 \leq h \leq 9 \\
-2 \leq k \leq 9 \\
-23 \leq l \leq 22\end{array}$ \\
\hline$a / \AA$ & 7.3082(4) A & Reflections Collected & 3687 \\
\hline $\boldsymbol{b} / \AA$ & 7.5105(4) A & Reflections Unique & 2067 \\
\hline$c / \AA ̊$ & $17.8511(9) \AA$ & $R 1$, wR2 (2ó) & $0.0473,0.0882$ \\
\hline$\alpha$ & $90^{\circ}$ & $R 1, w R 2$ (all) & $0.0711,0.0991$ \\
\hline$\beta$ & $90^{\circ}$ & Data / Parameters & $2062 / 154$ \\
\hline$\gamma$ & $90^{\circ}$ & GOOF of $F^{2}$ & 1.114 \\
\hline$V / \AA^{3}$ & $979.82(9)$ & Largest Difference Peak Hole /e $\AA^{-3}$ & 0.367 and -0.269 \\
\hline$Z$ & 4 & Crystal Size / mm & $0.44 \times 0.22 \times 0.06$ \\
\hline Calc. density / $\mathrm{g} \mathrm{cm}^{-3}$ & 1.760 & CCDC No & 1943903 \\
\hline$\mu / \mathbf{m m}^{-1}$ & 0.404 & & \\
\hline
\end{tabular}

Table 4. The list of inter- and intramolecular hydrogen bonds.

\begin{tabular}{|c|c|c|c|c|}
\hline$D-H \cdots A$ & $D \cdots H(\AA)$ & $H \cdots A(\AA)$ & $D \cdots A(\AA)$ & $D-H \cdots A\left({ }^{\circ}\right)$ \\
\hline $\mathrm{N} 4-\mathrm{H} 7 \cdots \mathrm{N3}^{\prime}$ & 0.92 & 2.58 & $2.934(6)$ & 109 \\
\hline $\mathrm{N} 4-\mathrm{H} 7 \cdots \mathrm{O} 4$ & 0.92 & 2.49 & $3.371(6)$ & 161 \\
\hline$N 4-H 10 \cdots O 1$ & 0.81 & 2.27 & $3.063(6)$ & 167 \\
\hline$N 5-H 11 \cdots N 3^{\prime}$ & 0.82 & 2.10 & $2.911(6)$ & 169 \\
\hline$N 5-H 12 \cdots O 1$ & 0.78 & 2.54 & $3.229(6)$ & 148 \\
\hline
\end{tabular}

Symmetry codes: $-1 / 2+x,-5 / 2-y, z ;-1 / 2+x,-5 / 2-y, z ;-x,-3-y, 1 / 2+z ; 1 / 2+x,-5 / 2-y, z ;-1 / 2-x$,

$-1 / 2+y, 1 / 2+z$ (respectively) 
mined. Single crystal data collection conditions and crystal data are listed in Table 3, important bond lengths and angles are shown in Supporting Information (Table S1), the intra- and intermolecular hydrogen bonds are listed in Table 4, and the molecular structure is drawn with Ortep program and hydrogen bonds and molecular interactions model is presented in Figures $6 a$ and $6 b^{46}$

As seen from Figure 6a, not all groups in the structure of the molecule 2 are in the same plane. There is an angle of $61.22^{\circ}$ between the plane of the N3C7N4N5 atoms that make up the guanidine unit and the plane of the aromatic ring. Similarly, the plane formed by the nitro groups is not parallel to the plane of the aromatic ring. The model is found to contain two $\mathrm{NH}_{2}$ on $\mathrm{C} 7$ atom. Under these circumstances, the hydrogen atoms on $\mathrm{N} 3, \mathrm{~N} 4$, and N5 are very labile and dislocate constantly due to resonance phenomena. A similar situation has been observed recently in $\mathrm{X}$-ray investigation of picrylguanidine. ${ }^{13,47}$

The resonance in the guanidine unit is clearly visible in the IR spectra. The double bond is constantly shifting around $\mathrm{C} 7$, but distancing from the plane of the molecule decreases the resonance, consequently, asymmetry can be observed around C7. The angles around the C7 atom are $119.9(4), 122.8(4)$ and $117.5(5)^{\circ}$. These values are close to $120^{\circ}$, despite to the bonds around $\mathrm{C} 7$ were found to be $1.329(6), 1.337(6)$ and 1.317(6) $\AA$ and these values indicate the probability of a $\mathrm{C}=\mathrm{N}$ double bond around $\mathrm{C} 7$. However, there are two $\mathrm{NH}_{2}$ groups bounded to $\mathrm{C} 7$ atom in the molecular structure. As can be seen from Table 4 and Figure $6 \mathrm{~b}$, important intra- and intermolecular five hydrogen bonds were found, one of which can be considered strong intermolecular hydrogen bond. The angle of the hydrogen bond formed between the hydrogen in N5 atom and N3 atom of the neighboring molecule is $169^{\circ}$ and the length is $2.911 \AA$, this cannot be classified as a strong hydrogen bond since strong hydrogen bonds are shorter than this. ${ }^{48-51} \mathrm{In}$ this study, it was not possible to obtain $N$-(5-chloro-2,4-dinitrophenyl)hydrazine (1) in suitable crystal sizes. Although $\mathrm{X}$-ray study of picrylhydrazine has been recently reported, the compound possesses a higher number of inter- and intramolecular bonds with much shorter bond lengths with predominating intermolecular interactions. ${ }^{9}$

Again, the hydrogen bond between the hydrogen in $\mathrm{N} 4$ atom and $\mathrm{N} 3$ atom of the neighboring molecule is in the class of strong hydrogen bonds. These strong hydrogen bonds increase intermolecular interaction, which is observed in thermal analysis, due to the strong intermolecular hydrogen bond, the molecule does not have a melting point up to $200{ }^{\circ} \mathrm{C}$, and the molecule gives a rapid thermal decomposition reaction around $240{ }^{\circ} \mathrm{C}$ and this thermal decomposition reaction is an explosion-like reaction.

\section{4. Thermokinetic Analysis}

The graphically calculated activation energy and Arrhenius pre-exponential factor values obtained by the use of OFW and KAS methods are tabulated in Table 5 and $\Delta H^{0}, \Delta S^{0}$ and $\Delta G^{0}$ calculated using these data in Table 6. The thermokinetic analysis of $\mathbf{1}$ could only be possible at low heating rates. Since this compound gives a rapid explosion at higher heating rates, there is a temperature decrease shortwhile after that and this makes the slopes of the curves positive which does not give any result. To overcome this problem, the kinetic studies were limited with the heating rates of $0.4,0.5,0.6,0.75$ and $1.0^{\circ} \mathrm{C} \mathrm{min}$. However, this causes the emergence of a new problem for the OFW. The logarithms of the values smaller than 1.0 are negative. Under such a situation, the OFW method is of no use. Therefore, only KAS method was employed for the thermokinetic investigation of this compound. There is no such problem for the other energetic materials 2 and 3 . $E_{\text {a }}$ and $A$ values for the two-step thermal decomposition of these compounds were separately determined.

As seen from Table 5, the results obtained from thermokinetic studies for compound $\mathbf{1}$ are not satisfactory. At the heating rates below $1{ }^{\circ} \mathrm{C} \mathrm{min}-1$ OFW technique is not useable since the logarithm of a number smaller than 1 is negative and it is not possible to compute the activation energy under these conditions. Although they can be calculated by the use of KAS and CR methods, the results are not reliable. Since TG curves change with the increasing heating rate the regression coefficients at high $g(\alpha)$ values are far from the acceptable limits. The values calculated for compound $\mathbf{1}$ in Table 6 are not statistically reliable. On the other hand, the values given for compounds $\mathbf{2}$ and $\mathbf{3}$ are comparable. Especially the results obtained for compound 2 by the use of OFW and KAS methods are very close to each other. This situation verifies the fact the nonisothermal-isoconvertional calculations in the thermokinetic computations indicated by ICTAC in 2011 are much more reliable. ${ }^{52-54}$ The OFW and KAS results of compound 3 are comparable. However, its CR calculation is different than those of OFW and KAS results. Since both OFW and KAS are non-isothermal graphic techniques the similarity between the results is an expected outcome. Table 6 lists the enthalpy $\left(\Delta H^{0}\right)$ values of the decomposition reactions of the energetic compounds investigated in this study. It was not possible to use OFW method for compound $\mathbf{1}$ for the use of lower heating rates. Since it is not possible to define the boundaries of the first and the second decomposition reactions of compound $\mathbf{1}$ all the calculations were carried out on the assumption that the compound gives a single step decomposition reaction at heating rates of $0.6,0.75$ and $1.0^{\circ} \mathrm{C}$ $\mathrm{min}^{-1}$. However, the $\Delta H^{0}$ value of compound $\mathbf{1}$ calculated by the assumption of single-step decomposition reaction is of comparable dimension with those of compounds $\mathbf{2}$ and 3 calculated based upon two-step decomposition. This shows the fact that the approach is not bad at all. However, the difficulty of the thermokinetic studies of energetic compounds is obvious. For very rapid reactions one has to use very low heating rates but if the thermal 
Table 5. The thermokinetic analysis results of energetic materials.

\begin{tabular}{|c|c|c|c|c|c|c|c|c|}
\hline \multirow{3}{*}{$\begin{array}{l}\text { Energetic } \\
\text { Material }\end{array}$} & \multicolumn{8}{|c|}{ Methods } \\
\hline & \multirow[b]{2}{*}{$g(\alpha)$} & \multicolumn{2}{|c|}{ OFW } & \multicolumn{3}{|c|}{ KAS } & \multicolumn{2}{|r|}{ CR } \\
\hline & & $E_{\mathrm{a}} / \mathrm{kJ} \mathrm{mol}^{-1}$ & $A / \min ^{-1}$ & $E_{\mathrm{a}} / \mathrm{kJ} \mathrm{mol}^{-1}$ & $A / \min ^{-1} \theta /$ & $/{ }^{\circ} \mathrm{C} \mathrm{min}^{-1}$ & ${ }^{-1} E_{\mathrm{a}} / \mathrm{kJ} \mathrm{mol}^{-1}$ & $A / \min ^{-1}$ \\
\hline \multirow[t]{2}{*}{ compound 1} & 0.2 & & & $160.50 \pm 1.26$ & $5.53 \pm 0.90 \times 10^{9}$ & 0.50 & $142.29 \pm 1.86$ & $2.09 \pm 0.06 \times 10^{10}$ \\
\hline & 0.4 & & & $179.33 \pm 8.74$ & $5.99 \pm 0.59 \times 10^{11}$ & $\begin{array}{ll}1 \quad 0.75\end{array}$ & $231.97 \pm 3.79$ & $1.44 \pm 0.08 \times 10^{20}$ \\
\hline \multirow[t]{4}{*}{$\mathrm{C}_{6} \mathrm{H}_{5} \mathrm{~N}_{4} \mathrm{O}_{4} \mathrm{Cl}$} & 0.5 & & & $183.14 \pm 21.63$ & $1.55 \pm 0.37 \times 10^{12}$ & $2 \quad 1.00$ & $200.69 \pm 1.86$ & $5.11 \pm 0.09 \times 10^{16}$ \\
\hline & 0.6 & & & $204.27 \pm 41.17$ & $2.06 \pm 0.84 \times 10^{14}$ & & & \\
\hline & 0.8 & & & $162.44 \pm 43.88$ & $1.04 \pm 0.56 \times 10^{10}$ & & & \\
\hline & & & & $177.94 \pm 17.79$ & & & $191.65 \pm 45.52$ & \\
\hline \multirow[t]{2}{*}{ compound 2} & 0.2 & \pm 0.37 & $5.11 \pm 0.05 \times 10^{9}$ & $76.98 \pm 0.14$ & $46.35 \pm 0.02$ & 5.0 & $79.51 \pm 0.95$ & $7.63 \pm 0.17 \times 10^{3}$ \\
\hline & 0.4 & $72.75 \pm 0.07$ & $2.78 \pm 0.01 \times 10^{9}$ & $66.69 \pm 0.02$ & $5.59 \pm 0.01$ & 10.0 & $76.39 \pm 0.47$ & $3.63 \pm 0.04 \times 10^{3}$ \\
\hline \multirow{3}{*}{$\mathrm{C}_{7} \mathrm{H}_{6} \mathrm{~N}_{5} \mathrm{O}_{4} \mathrm{Cl}$} & 0.5 & $71.66 \pm 0.36$ & $2.22 \pm 0.02 \times 10^{9}$ & $68.17 \pm 0.62$ & $7.81 \pm 0.13$ & 15.0 & $59.88 \pm 0.49$ & $68.75 \pm 0.10$ \\
\hline & 0.6 & $70.65 \pm 0.27$ & $1.76 \pm 0.01 \times 10^{9}$ & $65.65 \pm 0.48$ & $4.56 \pm 0.06$ & 20.0 & $66.17 \pm 0.60$ & $299.93 \pm 0.05$ \\
\hline & 0.8 & $65.01 \pm 0.56$ & $4.84 \pm 0.07 \times 10^{8}$ & $48.78 \pm 5.76$ & $0.14 \pm 0.00$ & & & \\
\hline \multirow[t]{6}{*}{ 1. Thermal Step } & & $71.22 \pm 4.01$ & & $65.25 \pm 10.24$ & & & $70.49 \pm 9.08$ & \\
\hline & 0.2 & $64.12 \pm 0.81$ & $4.28 \pm 0.09 \times 10^{7}$ & $57.39 \pm 0.74$ & $0.085 \pm 0.0$ & 5.0 & $66.93 \pm 0.10$ & $32.69 \pm 0.01$ \\
\hline & 0.4 & $83.82 \pm 0.70$ & $2.64 \pm 0.04 \times 10^{9}$ & $77.84 \pm 0.66$ & $4.81 \pm 0.07$ & 10.0 & $68.57 \pm 0.50$ & $130.04 \pm 0.02$ \\
\hline & 0.5 & $97.50 \pm 2.45$ & $3.01 \pm 0.12 \times 10^{10}$ & $92.60 \pm 2.03$ & $58.09 \pm 0.20$ & 15.0 & $132.12 \pm 1.31$ & $1.03 \pm 0.02 \times 10^{7}$ \\
\hline & 0.6 & $108.21 \pm 1.71$ & $2.26 \pm 0.06 \times 10^{11}$ & $103.17 \pm 1.62$ & $377.51 \pm 0.09$ & 20.0 & $140.74 \pm 3.22$ & $8.09 \pm 0.28 \times 10^{7}$ \\
\hline & 0.8 & $115.08 \pm 0.92$ & $7.91 \pm 0.10 \times 10^{11}$ & $110.17 \pm 0.87$ & $1.26 \pm 0.01 \times 10^{3}$ & & & \\
\hline 2. Thermal Step & & $93.75 \pm 20.34$ & & $88.23 \pm 21.11$ & & & $102.09 \pm 39.81$ & \\
\hline \multirow[t]{2}{*}{ compound 3} & 0.2 & $41.63 \pm 0.55$ & $1.72 \pm 0.04 \times 10^{6}$ & $34.60 \pm 0.46$ & $0.52 \pm 0.01$ & 5.0 & $107.99 \pm 0.50$ & $1.47 \pm 0.01 \times 10^{6}$ \\
\hline & 0.4 & $46.13 \pm 0.25$ & $6.44 \pm 0.06 \times 10^{6}$ & $39.08 \pm 0.22$ & $0.47 \pm 0.01$ & 10.0 & $102.62 \pm 0.23$ & $9.80 \pm 0.04 \times 10^{5}$ \\
\hline \multirow[t]{3}{*}{$\mathrm{C}_{9} \mathrm{H}_{6} \mathrm{~N}_{5} \mathrm{O}_{4} \mathrm{Cl}$} & 0.5 & $47.00 \pm 0.09$ & $8.57 \pm 0.03 \times 10^{6}$ & $39.83 \pm 0.08$ & $0.55 \pm 0.01$ & 15.0 & $78.06 \pm 0.19$ & $2.70 \pm 0.01 \times 10^{3}$ \\
\hline & 0.6 & $47.92 \pm 0.09$ & $1.13 \pm 0.01 \times 10^{7}$ & $40.70 \pm 0.08$ & $0.59 \pm 0.01$ & 20.0 & $122.28 \pm 0.41$ & $2.64 \pm 0.02 \times 10^{7}$ \\
\hline & 0.8 & $48.00 \pm 0.07$ & $1.26 \pm 0.01 \times 10^{7}$ & $40.63 \pm 0.05$ & $0.97 \pm 0.01$ & & & \\
\hline \multirow[t]{6}{*}{ 1. Thermal Step } & & $46.14 \pm 2.63$ & & $38.97 \pm 2.53$ & & & $102.74 \pm 18.42$ & \\
\hline & & $110.88 \pm 0.89$ & $1.60 \pm 0.02 \times 10^{11}$ & $97.15 \pm 1.92$ & $55.20 \pm 0.17$ & 5.0 & $85.05 \pm 0.94$ & $595.95 \pm 0.10$ \\
\hline & & $135.06 \pm 2.70$ & $1.97 \pm 0.06 \times 10^{13}$ & $101.25 \pm 1.76$ & $160.48 \pm 0.04$ & 10.0 & $97.85 \pm 2.53$ & $1.05 \pm 0.04 \times 10^{4}$ \\
\hline & & $142.48 \pm 3.70$ & $6.98 \pm 0.28 \times 10^{13}$ & $104.44 \pm 2.94$ & $268.45 \pm 0.11$ & 15.0 & $93.43 \pm 1.49$ & $4.35 \pm 0.11 \times 10^{3}$ \\
\hline & & $139.67 \pm 3.63$ & $3.70 \pm 0.14 \times 10^{13}$ & $103.80 \pm 4.13$ & $228.05 \pm 0.14$ & 20.0 & $112.23 \pm 3.37$ & $1.74 \pm 0.08 \times 10^{5}$ \\
\hline & & $150.98 \pm 3.18$ & $2.00 \pm 0.06 \times 10^{14}$ & $120.11 \pm 4.13$ & $2.87 \pm 0.14 \times 10^{3}$ & & & \\
\hline 2. Thermal Step & & $135.81 \pm 15.09$ & & $105.35 \pm 8.73$ & & & $97.14 \pm 11.37$ & \\
\hline
\end{tabular}

Table 6. The calculated thermodynamic values of the energetic materials prepared for the thermal decomposition reactions.

\begin{tabular}{|c|c|c|c|c|c|c|c|c|c|}
\hline \multirow{2}{*}{$\begin{array}{l}\text { Energetic } \\
\text { Material }\end{array}$} & \multicolumn{9}{|c|}{ Methods } \\
\hline & $\begin{array}{c}\Delta H / \\
\mathrm{kJ} \mathrm{mol}^{-1}\end{array}$ & $\begin{array}{c}\Delta S / \\
\mathrm{J} \mathrm{K}^{-1}\end{array}$ & $\begin{array}{c}\Delta G / \\
\mathrm{kJ} \mathrm{mol}^{-1}\end{array}$ & $\begin{array}{c}\Delta H / \\
\mathrm{kJ} \mathrm{mol}^{-1}\end{array}$ & $\begin{array}{c}\Delta S / \\
\mathrm{J} \mathrm{K}^{-1}\end{array}$ & $\begin{array}{c}\Delta G / \\
\mathrm{kJ} \mathrm{mol}^{-1}\end{array}$ & $\begin{array}{c}\Delta H / \\
\mathrm{kJ} \mathrm{mol}^{-1}\end{array}$ & $\begin{array}{c}\Delta S / \\
\mathrm{J} \mathrm{K}^{-1}\end{array}$ & 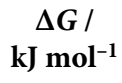 \\
\hline $\mathrm{C}_{6} \mathrm{H}_{5} \mathrm{~N}_{4} \mathrm{O}_{4} \mathrm{Cl}(\mathbf{1})$ & & & & 176.27 & -15.82 & 184.17 & 189.98 & 136.74 & 121.74 \\
\hline \multicolumn{10}{|l|}{$\mathrm{C}_{7} \mathrm{H}_{6} \mathrm{~N}_{5} \mathrm{O}_{4} \mathrm{Cl}(2)$} \\
\hline 1. Thermal Step & 69.21 & -70.93 & 107.49 & 63.24 & -232.79 & 192.65 & 68.48 & -181.72 & 166.55 \\
\hline 2. Thermal Step & 91.04 & -50.46 & 122.52 & 85.52 & -217.31 & 221.10 & 99.38 & -210.61 & 230.78 \\
\hline \multicolumn{10}{|l|}{$\mathrm{C}_{9} \mathrm{H}_{6} \mathrm{~N}_{5} \mathrm{O}_{4} \mathrm{Cl}(3)$} \\
\hline 1. Thermal Step & 44.05 & -117.29 & 108.54 & 36.88 & -255.01 & 177.10 & 100.65 & -135.32 & 175.06 \\
\hline 2. Thermal Step & 133.09 & 13.96 & 124.36 & 102.63 & -204.60 & 230.54 & 94.42 & -174.11 & 203.27 \\
\hline
\end{tabular}

decomposition reaction gives the curve expected from TG analysis as is the case for the energetic compounds 2 and 3 , the results are highly useable. What is the logic for the thermokinetic studies of energetic compounds? This point is under discussion as is the validity of Kissinger equation. ${ }^{55}$ 


\section{5. Computational Results}

The electron density maps and HOMO-LUMO overlap images are illustrated in Figure 7. The calculated formation enthalpies $\left(\mathrm{kJ} \mathrm{mol}^{-1}\right)$ and the smallest HOMO-LU$\mathrm{MO}$ energy differences $(\mathrm{eV})$ are listed in Table 7 . In electron density maps the blue areas correspond to the electron-rich and the red areas correspond to the electron-poor regions. According to the Kamlet-Jacobs equation the calculated oxygen balance $(\Omega)$, theoretical detonation velocity $(D)$ and detonation pressure $(P)$ values are given in Table 8.

\section{Electron Distribution Map}

a

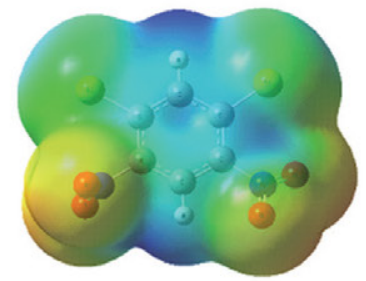

b

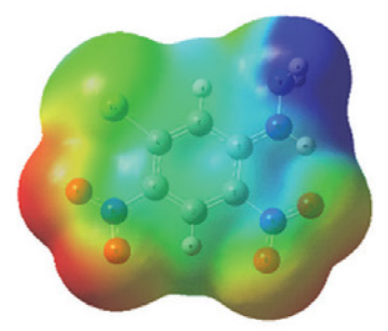

C

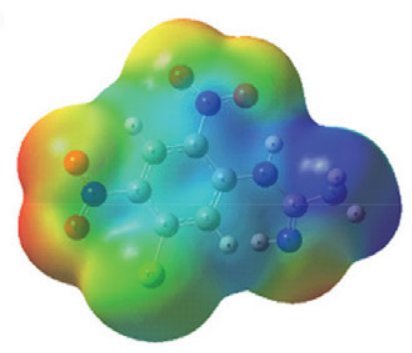

d

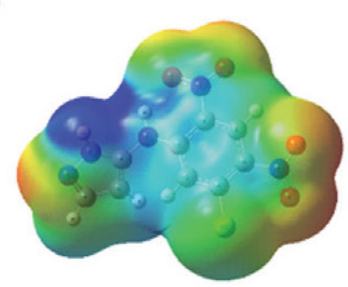

HOMO Overlaps

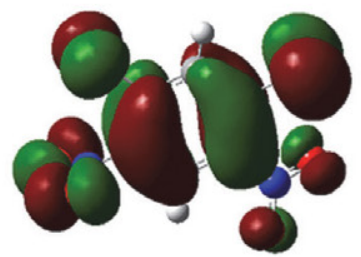

\section{LUMO Overlaps}
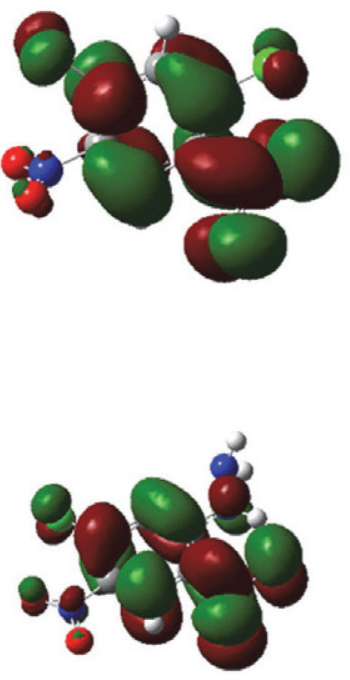
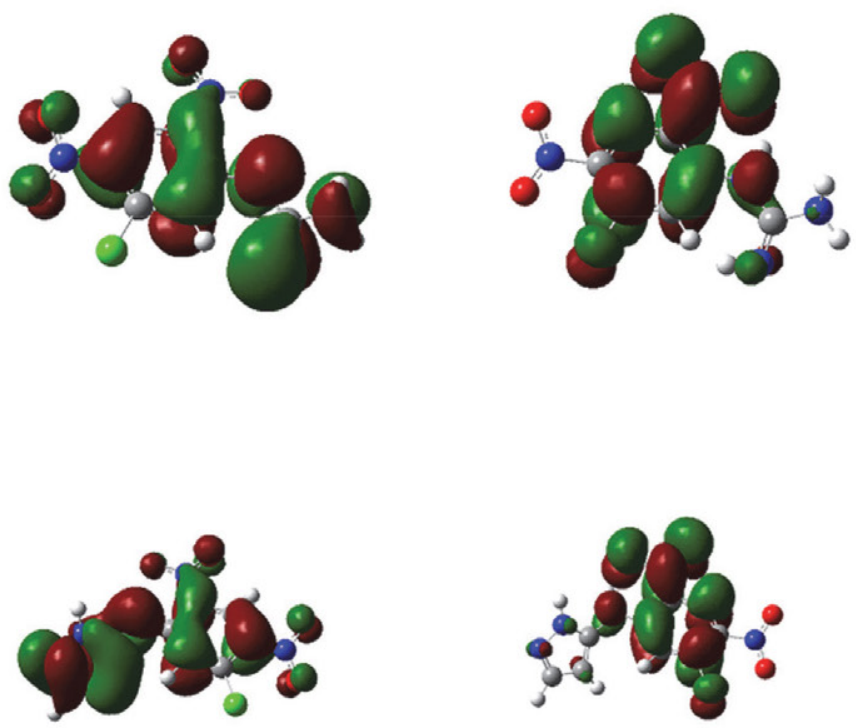

Figure 7. Electron density distribution and HOMO and LUMO images of the energetic molecules prepared, a: 1,3-dichloro-4,6-dinitrobenzene, b: $N$-(5-chloro-2,4-dinitrophenyl)hydrazine (1), c: $N$-(5-chloro-2,4-dinitrophenyl)guanidine (2), d: $N$-(5-chloro-2,4-dinitrophenyl)-4-aminopyrazole (3) 
Table 7. The energy levels of the highest energy HOMO and lowest energy LUMO, calculated theoretical dipole moment and formation enthalpy values of the energetic materials prepared.

\begin{tabular}{lccccc}
\hline Energetic Compound & $\boldsymbol{E}_{\mathrm{HOMO}} / \mathbf{e V}$ & $\boldsymbol{E}_{\mathrm{LUMO}} / \mathbf{e V}$ & $\boldsymbol{\Delta} \boldsymbol{E} / \mathbf{e V}$ & $\boldsymbol{\mu} / \mathbf{D}$ & $\boldsymbol{\Delta} \boldsymbol{H}_{\mathrm{f}}^{\mathbf{o}} / \mathbf{k J} / \mathbf{m o l}$ \\
\hline 1,3-dichloro-4,6-dinitro-benzene & -7.948 & -3.193 & 4.755 & 3.55 & 458.832 \\
$\mathbf{1}$ & -6.905 & -2.902 & 4.003 & 7.66 & 386.290 \\
$\mathbf{2}$ & -7.073 & -3.215 & 3.858 & 5.01 & 372.217 \\
$\mathbf{3}$ & -6.711 & -3.203 & 3.508 & 4.10 & 338.506 \\
\hline
\end{tabular}

Table 8. Calculated detonation properties of the energetic materials prepared.

\begin{tabular}{lcccccr}
\hline Component & $\begin{array}{c}\boldsymbol{V}_{\text {calc }} / \\
\mathbf{c m}^{\mathbf{3}} \mathbf{~ m o l}^{-\mathbf{1}}\end{array}$ & $\begin{array}{c}\boldsymbol{\rho}_{\text {calc }} / \\
\mathbf{g ~ c m}^{-3}\end{array}$ & $\begin{array}{c}\boldsymbol{\Omega} / \\
\mathbf{9}\end{array}$ & $\begin{array}{c}\boldsymbol{Q} / \\
\mathbf{k c a l ~ g}^{-\mathbf{1}}\end{array}$ & $\begin{array}{c}\boldsymbol{D} / \\
\mathbf{k m ~ s}\end{array}$ & $\begin{array}{c}\boldsymbol{P} / \\
\mathbf{k b a r}\end{array}$ \\
\hline 1,3-dichloro-4,6-dinitrobenzene & 129.140 & 1.15 & -0.54 & 835.8 & 3.92 & 4.99 \\
$\mathbf{1}$ & 127.646 & 1.82 & -0.69 & 1047.4 & 6.54 & 19.07 \\
$\mathbf{2}$ & 173.358 & $1.76^{\mathrm{a}}$ & -0.77 & 918 & 6.17 & 16.66 \\
$\mathbf{3}$ & 172.192 & 1.25 & -0.93 & 949.9 & 4.75 & 7.81 \\
\hline
\end{tabular}

${ }^{\text {a } X-r a y ~ d a t a ~}$

The theoretical results are tabulated in Table 7. The formation enthalpies or $\Delta H_{\mathrm{f}}^{0}$ values of the compounds $\mathbf{1 , 2}$ and 3 are listed as $386.290,372.217$, and $338.506 \mathrm{~kJ} \mathrm{~mol}^{-1}$, respectively which also indicate the order of the stability of these compounds. The most stable one among them is compound 3 with the smallest $\Delta H_{\mathrm{f}}^{0}$ value. This is highly commendable since there are two aromatic rings connected to each other in this compound. The theoretically calculated dipole moments also show parallelism with this result. Since dipole moments are the measure of electron distribution the homogeneity of the electron distribution changes in parallel with the dipole moment and $\Delta H_{\mathrm{f}}{ }^{0}$ values. The only unexpected result of the theoretical calculations is the difference in energy between HOMO and LUMO levels which is the measure of the thermal sensitivity of energetic materials. ${ }^{56}$ Theoretically calculated detonation heat, detonation pressure and detonation velocity values are given in Table 8 using the formation enthalpy values, densities and oxygen balance values of the energetic substances prepared. Only the density value of energetic compound 2 was determined with X-ray study, others were theoretically calculated. The detonation velocity and detonation pressure values were calculated in parallel with the formation enthalpy values of energetic substances and this is an expected result. This case shows the success of the Gaussian 09 program because the experimental density of the energetic substance 2 lies within a suitable range between theoretical densities.

The smaller is this difference, the smaller is the thermal sensitivity. Therefore, the compound with the highest thermal sensitivity is compound $\mathbf{3}$. However, this is also the compound with the highest thermal decomposition temperature. This contradiction is attributed to probable intermolecular interactions. When we consider the dipole moments the compound with the highest intermolecular forces is compound $\mathbf{1}$. By the effect of these forces, the molecule may preserve its solid-state properties up to a certain temperature and have a sudden decomposition. There are numerous examples of this situation in the literature. ${ }^{57}$ Therefore, the compound $\mathbf{1}$ behaves differently than compounds 2 and 3.

\section{6. Antibacterial Activity}

For bioactivity determination, Gram negative (Escherichia coli-ATCC 25922, Pseudomonas aeruginosa-ATCC 27853, Salmonella enteritidis-ATCC35311) and Gram positive (Enterococcus faecalis, Bacillus subtilis-DSM 1971, Staphilococcus aureus-ATCC 25953, Bacillus licheniformis-DSM 13) bacterial strains were tested against $\mathbf{1}, \mathbf{2}$, and $\mathbf{3}$ in $8-512 \mathrm{mg} / \mathrm{L}$ concentration range. It was shown that compounds 1, 2, and 3 were especially effective against Gram negative species and compound $\mathbf{2}$ is the most effective compound concerning antibacterial activity having 8-16 mg/L MIC values for Gram negative strains and being the only effective agent against Gram positive strains. B. licheniformis was found to be the most susceptible bacterial strain against the energetic compounds tested in this study. The complete results are given in Table 9. Generally speaking, E. coli is not affected by these energetic substances, however $P$. aeruginosa is affected even at low concentrations and the bacterial population is decreased. There are two major reasons to investigate the antimicrobial properties of energetic compounds. The first one is to determine whether they have any lethal effect upon the microbial organisms. The second reason was just the opposite of whether they might have nutritious effect on the bacteria. The results listed in Table 9 show the fact that the energetic materials do not have any lethal effect upon the bacteria. On the contrary, they may provide a nutrition 
Table 9. The antimicrobial tests results of the energetic materials toward seven different bacteria.

\begin{tabular}{|c|c|c|c|c|c|c|c|c|c|c|c|c|c|c|c|c|c|c|c|c|c|}
\hline \multirow{2}{*}{$\begin{array}{l}\text { Energetic } \\
\text { Material } \\
\left(\mathrm{mg} \mathrm{L}^{-1}\right)\end{array}$} & \multicolumn{3}{|c|}{$\begin{array}{c}E . \\
\text { coli }\end{array}$} & \multicolumn{3}{|c|}{$\begin{array}{c}E . \\
\text { faecalis }\end{array}$} & \multicolumn{3}{|c|}{$\begin{array}{c}\text { B. } \\
\text { subtilis }\end{array}$} & \multicolumn{3}{|c|}{$\begin{array}{c}\text { S. } \\
\text { aureus }\end{array}$} & \multicolumn{3}{|c|}{$\begin{array}{c}P . \\
\text { aeruginosa }\end{array}$} & \multicolumn{3}{|c|}{$\begin{array}{c}S . \\
\text { enteritidis }\end{array}$} & \multicolumn{3}{|c|}{$\begin{array}{c}\text { B. } \\
\text { licheniformis }\end{array}$} \\
\hline & 1 & 2 & 3 & 1 & 2 & 3 & 1 & 2 & 3 & 1 & 2 & 3 & 1 & 2 & 3 & 1 & 2 & 3 & 1 & 2 & 3 \\
\hline 512 & + & - & + & + & - & + & + & - & - & - & - & - & + & + & + & + & + & - & - & - & - \\
\hline 256 & + & + & + & + & - & + & + & - & - & - & - & - & + & + & + & + & + & - & - & - & - \\
\hline 128 & + & + & + & + & - & + & + & - & - & + & - & - & + & + & + & + & + & + & - & - & - \\
\hline 64 & + & + & + & + & - & + & + & - & - & + & - & - & + & + & + & + & + & + & + & - & - \\
\hline 32 & + & + & + & + & + & + & + & + & + & + & - & - & + & + & + & + & + & + & + & + & + \\
\hline 16 & + & + & + & + & + & + & + & + & + & + & - & + & + & + & + & + & + & + & + & + & + \\
\hline 8 & + & + & + & + & + & + & + & + & + & + & + & + & + & + & + & + & + & + & + & + & + \\
\hline
\end{tabular}

Note: + sign indicates that the bacterial population has increased, and the - sign indicates that the bacterial population does not increase.

source to microbial organisms. The compound $\mathbf{1}$ acted as a nutrition source for all the microorganisms investigated. The energetic compounds are rich in nitrogen. Nitrogen is in positive oxidation state in nitro group and in negative oxidation state in amino groups attached to the molecule. That is why all the bacteria among the compounds used especially compound $\mathbf{1}$ as a nutrition source in cultured medium. The energetic compounds $\mathbf{2}$ and $\mathbf{3}$ showed an antimicrobial effect on a microbial concentration of $64 \mathrm{mg} / \mathrm{L}$. The compound with the highest antimicrobial effect is compound 2. This is due to guanidine group attached to the molecule. Guanidines have been used as an antiseptic agents in gastro systems. ${ }^{58}$

Also, the antimicrobial studies must be extended to environmental dimensions. The elimination of the ammunition which completed their practical lives constitutes a very big problem. The only solution today is burning the outdated material. This is a dangerous and risky process. Microbial degradation can be a much less risky alternative to it.

\section{Conclusion}

Three new energetic materials were prepared using 1,3-dinitro-4,6-dichlorobenzene with nucleophilic substitution reactions and these energetic materials were investigated by thermogravimetry. It was observed that thermal decomposition of these energetic materials occurs in two steps and these two-step reaction can be observed at low heating rates. Thermogravimetric results showed that the intermediate product is furoxane ring in thermal decomposition. Besides, although these energetic materials contained nitro groups, it was seen that they do not have a strong toxic effect on seven different bacteria and on the contrary they are nutrient materials for some bacteria.

\section{Acknowledgments}

This research did not receive any specific grant from funding agencies. The authors declare that there is no conflict of interest.

\section{References}

1. J. P. Agrawal: High Energy Materials, Wiley-VCH, Weinheim, Germany, 2010, pp. 141-144.

2. D. M. Badgujar, M. B. Talawar, S. N. Asthana, P. P. Mahulikar, J. Hazard. Mat. 2008, 151(2-3), 289-305.

DOI:10.1016/j.jhazmat.2007.10.039

3. T. M. Klapötke: Chemistry of the High Energy Materials, Walter de Gruyter, Berlin, Germany, 2017, pp. 299-305. DOI:10.1515/9783110536515

4. F. A. Carey, R. J. Sundberg: Advanced Organic Chemistry, Springer, New York, USA, 2007, pp. 817-821.

5. N. Ono: The Nitro Group in Organic Synthesis, Wiley-VCH, Weinheim, Germany, 2001, pp. 309-316.

DOI: $10.1002 / 0471224480$

6. J. P. Agrawal, R. D. Hogdson: Organic Chemistry of Explosives, John Wiley \& Sons, West Sussex, England, 2007, pp. 157-159.

7. J. P. Agrawal: High Energy Materials, Wiley-VCH, Weinheim, Germany, 2010, pp. 82-102.

8. A. B. Sheremetev, N. S. Aleksandrova, N. V. Ignatev, M. Schulte, Mendeleev Comm. 2012, 22(2), 95-97.

DOI:10.1016/j.mencom.2012.03.015

9. A. Ö. Yiğiter, M. K. Atakol, M. L. Aksu, O. Atakol, J. Therm. Anal. Calorim. 2017, 127, 2199-2123.

DOI:10.1007/s10973-016-5766-2

10. M. K. Atakol, A. Atakol, A. Ö. Yiğiter, I. Svoboda, O. Atakol, J. Therm. Anal. Calorim. 2017, 127, 1931-1940.

DOI:10.1007/s10973-016-5800-4

11. E. Özkaramete, N. Şenocak, E. K. İnal, S. Öz, I. Svoboda, O. Atakol, Propellants, Explosives, Pyrotechnics 2013, 38(1), 113119. DOI:10.1002/prep.201200075

12. M. B. Talawar, R. Sivabalan, T. Mukundan, H. Muthurajan, A. K. Sikder, B. R. Gandhe, A. S. Rao, J. Hazard. Mat. 2009, 161(2-3), 589-607. DOI:10.1016/j.jhazmat.2008.04.011

13. T. M. Klapötke, F. Mieskes, J. Stierstorfer, M. Weyrauther, Propellants, Explosives, Pyrotechnics 2016, 41(2), 217-222. DOI:10.1002/prep.201500338

14. P. Leonard, P. Bowden, M. Shorty, M. Schmitt, Propellants, Explosives, Pyrotechnics 2019, 44(2), 203-206.

DOI:10.1002/prep.201800144 
15. N. Koga, J. Therm. Anal. Calorim. 2013, 113, 1527-1541. DOI:10.1007/s10973-012-2882-5

16. S. Kullyakool, K. Siriwong, P. Noisong, C. Danvirutai, J. Therm. Anal. Calorim. 2017, 127, 1963-1974.

DOI:10.1007/s10973-016-5837-4

17. L. Abdelouahed, S. Leveneur, L. V. Hassimi, L. Balland, B. Taouk, J. Therm. Anal. Calorim. 2017, 129, 1201-1213. DOI:10.1007/s10973-017-6212-9

18. K. Jayaraman, M. V. Kok, I. Gokalp, J. Therm. Anal. Calorim. 2017, 127, 1361-1370. DOI:10.1007/s10973-016-6042-1

19. J. Zhao, B. Jin, R. Peng, Q. Liu, B. Tan, S. Chu, J. Therm. Anal. Calorim. 2016, 124, 1431-1439.

DOI:10.1007/s10973-016-5315-Z

20. Y. F. Li, L. J. Zhai, K. Z. Xu, B. Z. Wang, J. R. Song, F. Q. Zhao, J. Therm. Anal. Calorim. 2016, 126, 1167-1173. DOI:10.1007/s10973-016-5662-9

21. F. Bao, G. Zhang, S. Jin, C. Zhang, H. Niu, J. Therm. Anal. Calorim. 2018, 132, 805-811. DOI:10.1007/s10973-018-6973-9

22. L. Luo, B. Jin, R. Peng, Y. Shang, L. Xiao, S. Chu, J. Therm. Anal. Calorim. 2019, 135, 3005-3013.

DOI:10.1007/s10973-018-7481-7

23. X. Yin, J. Li, G. Zhang, H. Gu, Q. Ma, S. Wang, J. Wang, J. Therm. Anal. Calorim. 2019, 135, 2317-2328.

DOI:10.1007/s10973-018-7390-9

24. A. Krajníková, A. Rotaru, K. Győryová, K. Homzová, H. O. Manolea, J. Kovářová, D. Hudecová, J. Therm. Anal. Calorim. 2015, 120, 73-83. DOI:10.1007/s10973-014-4212-6

25. A. Suekkhayad, P. Noisong, C. Danvirutai, J. Therm. Anal. Calorim. 2017, 129, 123-134.

DOI:10.1007/s10973-017-6156-0

26. E. C. Moine, R. Bouamoud, A. El Hamidi, M. Khachani, M. Halim, S. Arsalane, J. Therm. Anal. Calorim. 2018, 131, 9931004. DOI:10.1007/s10973-017-6632-6

27. N. S. Abdel-Kader, R. M. Amin, A. L. El-Ansary, J. Therm. Anal. Calorim. 2016, 123, 1695-1706.

DOI:10.1007/s10973-015-5015-0

28. J. Naktiyok, H. Bayrakçeken, A. K. Özer, M. Ş. Gülaboğlu, J. Therm. Anal. Calorim. 2017, 129, 531-539.

DOI:10.1007/s10973-017-6149-Z

29. G. Ganeshan, K. P. Shadangi, K. Mohanty, J. Therm. Anal. Calorim. 2018, 131, 1803-1816.

DOI:10.1007/s10973-017-6597-5

30. M. J. Frisch, G. W. Trucks, H. B. Schlegel, G. E. Scuseria, M. A. Robb, J. R. Cheeseman, G. Scalmani, V. Barone, B. Mennucci, G. Petersson, H. Nakatsuji: Gaussian 09, Revision D. 01, Gaussian. Inc., Wallingford CT, 2009.

31. CrysAlis C. CrysAlis RED, Version 1.171. Oxford Diffraction Ltd., Abdingdon, UK, 2002.

32. G. M. Sheldrick, Acta Cryst. C. 2015, 71, 3-8.

DOI:10.1107/S2053229614024218

33. L. J. Farrugia, J. Appl. Crystallogr. 1999, 32, 837-838.

DOI:10.1107/S0021889899006020

34. L. A. Curtiss, K. Raghavachari, P. C. Redfern, J. A. Pople, J. Chem. Phys. 1997, 106, 1063-1079. DOI:10.1063/1.473182

35. E. F. C. Byrd, B. M. Rice, J. Phys. Chem. A 2009, 110(3), 10051013. DOI:10.1021/jp0536192
36. B. M. Rice, S. V. Pai, J. Hare, Combust. Flame 1999, 118(3), 445-458. DOI:10.1016/S0010-2180(99)00008-5

37. P. J. Linstrom, W. G. Mallard, NIST standard reference database number 69, National Institute of Standards and Technology, http://webbook.nist.gov (accessed: July, 2018).

38. D. S. Y. Gaelle, D. M. Yufanyi, R. Jagan, M. O. Agwara, Cogent Chem. 2016, 2(1), 1253201.

DOI: $10.1080 / 23312009.2016 .1253201$

39. H. F. Abd El-Halim, M. M. Omar, M. N. Anwar, J. Therm. Anal. Calorim. 2017, 130, 1069-1083.

DOI:10.1007/s10973-017-6491-1

40. O. A. M. Ali, J. Therm. Anal. Calorim. 2017, 128, 1579-1590. DOI:10.1007/s10973-016-6055-9

41. J. Akhavan: The Chemistry of Explosives, Royal Society of Chemistry Publishing, Cambridge, UK, 1998.

42. A. S. Bailey, J. R. Case, Tetrahedron 1958, 3, 113-131. DOI:10.1016/0040-4020(58)80003-4

43. G. O. Reddy, B. K. M. Murall, A. K. Chotterjee, Propellants, Explosives, Pyrotechnics 1983, 8(1), 29-33.

DOI:10.1002/prep.19830080107

44. J. Kehler, A. Püschl, O. Dahl, Acta Chem. Scand. 1996, 50, 1171-1173. DOI:10.3891/acta.chem.scand.50-1171

45. P. Cardillo, L. Gigante, A. Lunghi, P. Zanirato, J. Therm. Anal. Calorim. 2010, 100(1), 191-198.

DOI:10.1007/s10973-009-0572-8

46. A. L. Spek: PLATON Program for Crystal Molecular Drawing, University of Utrecht, Netherlands, 2000.

47. G. Smith, U. D. Vermuth, J. M. White, Acta Cryst. E 2007, 63, o3759. DOI:10.1107/S1600536807038068

48. T. Steiner, Angew. Chem. Int. Ed. 2002, 41(1), 48-76. DOI:10.1002/1521-3773(20020104)41:1<48::AID-ANIE48> 3.0.CO;2-U

49. G. R. Desiraju, Acc. Chem. Res. 1996, 29(9), 441-449. DOI:10.1021/ar950135n

50. P. K. Thallapally, A. K. Katz, H. L. Carrel, G. R. Desiraju, Cryst. Eng. Comm. 2003, 5, 87-92. DOI:10.1039/b301677c

51. S. Mirdya, M. G. B. Drew, A. K. Chandra, A. Banerjee, A. Frontera, S. Chattopadhyay, Polyhedron, 2020, 179, 114374. DOI:10.1016/j.poly.2020.114374

52. S. Vyazovkin, A. K. Burnham, J. M. Criado, L. A. Perez-Magueda, C. Popescu, N. Sbirazzuoli, Thermochim. Acta 2011, 520(1-2), 1-19. DOI:10.1016/j.tca.2011.03.034

53. S. Vyazovkin, K. Chrissafis, M.L. Di Lorenzo, N. Koga, M. Pijolat, B. Roduit, N. Sbirrazzuoli, J. J. Suñol, Thermochim. Acta 2014, 590, 1-23. DOI:10.1016/j.tca.2014.05.036

54. M. E. Brown, M. Maciejewski, S. Vyazovkin, R. Nomen, J. Sempere, A. Burnham, J. Opfermann, R. Strey, H. L. Anderson, A. Kemmler, R. Keuleers, J. Janssens, H. O. Desseyn, C. R. Li, T. B. Tang, B. Roduit, J. Malek, T. Mitsuhashi, Thermochim. Acta 2000, 355(1-2), 125-143.

DOI:10.1016/S0040-6031(00)00443-3

55. J. Sestak, J. Them. Anal. Calorim. 2014, 117, 3-7. DOI:10.1007/s10973-014-3810-7

56. X. Liu, Z. Su, W. Ji, S. Chen, Q. Wei, G. Xie, X. Yang, S. Gao, J. Phys. Chem. C 2014, 118(41), 23487-23498.

DOI:10.1021/jp5062418 
57. T. M. Klapötke: Chemistry of the High Energy Materials, Walter de Gruyter, Berlin, Germany, 2017, pp. 7.

DOI:10.1515/9783110536515
58. L. F. Fieser, M. Fieser: Lehrbuch der Organischen Chemie, Verlag Chemie GMBH, Weinheim, Germany, 1954, pp. 1176-1178.

\section{Povzetek}

$\mathrm{Z}$ reakcijo nukleofilne substitucije smo iz 1,3-dikloro-4,6-dinitrobenzena s hidrazinom, gvanidinijevim karbonatom oz. 4-aminopirazolom pripravili tri nove dušikove energetske spojine: $N$-(5-kloro-2,4-dinitrofenil)hidrazin (1), $N$-(5-kloro2,4-dinitrofenil)gvanidin (2) in $\mathrm{N}$-(5-kloro-2,4-dinitrofenil)-4-aminopirazol (3). Spojine smo karakterizirali z ${ }^{1} \mathrm{H}$ NMR, ${ }^{13} \mathrm{C}$ NMR, IR in masno spektroskopijo. Samo spojino 2 smo lahko pripravili v obliki kristalov, primernih za rentgensko difrakcijsko analizo. Spojine smo raziskali tudi s TG in DSC. Termični razpad in termokinetično obnašanje smo raziskali s pomočjo metod, ki so jih razvili Ozawa-Flynn-Wall ter Kissinger-Akahira-Sunose. Opazili smo, da $\mathrm{z}$ raziskovanimi spojinami lahko poteka eksotermen termični razpad. S pomočjo Gaussian09 smo izračunali HOMO in LUMO nivoje, teoretične tvorbene entalpije in porazdelitev elektrostatskega naboja. Eksplozijske hitrosti in tlake smo izračunali s pomočjo Kamlet-Jacobsovih enačb. Spojinam smo določili tudi antimikrobne lastnosti.

Except when otherwise noted, articles in this journal are published under the terms and conditions of the Creative Commons Attribution 4.0 International License 